\title{
The Effect of the Covid-19 Pandemic on Stress Learning
}

\author{
Qorri 'Ainan Salsabila \\ Universitas Negeri Jakarta, Indonesia \\ qiansalsalsabila@gmail.com \\ Zachrina Aqinar \\ Universitas Negeri Jakarta, Indonesia \\ zachrinaaqinar@gmail.com \\ Muhamad Ridwan Effendi \\ Universitas Negeri Jakarta, Indonesia \\ muhamadridwan@unj.ac.id
}

DOI: https://doi.org/10.52593/pdg.02.2.01

Naskah diterima: 26 Juli 2021, direvisi: 27 Juli 2021, disetujui: 28 Juli 2021

\begin{abstract}
The low learning ethic of the participants in the learning process who was brave throughout the Covid-19 pandemic was shown by the attitude of students who did not appreciate the learning process, even they had fun in their world (such as playing games, streaming Youtube, sleeping, travelling) without a teacher is learning stress. Learning stress or academic stress is a category of distress in which students perceive academic demands as disturbing. It can also be interpreted as pressure related to the ability to master a science. Symptoms of learning stress include physical reactions, behaviour, thought processes, and emotions. Based on various research results, the level of learning stress increases during the COVID-19 pandemic. This is considered related to the change in the face-to-face learning system to online (in the network), which raises new factors as triggers for learning stress. This research was conducted to determine how the COVID19 pandemic affects stress in learning and find solutions to overcome feelings of stress in learning, especially solutions from an Islamic perspective. The method used by the author in this study is a qualitative method with a literature study approach with analysis of the theory of Robert J. Van Amberg about the stages of stress. The results of the study revealed that learning stress factors during the covid-19 pandemic were in the form of lack of understanding of the material, a lot of assignments, declining grades, a tiring and boring learning system, quota constraints and internet networks, individual internal factors, and social factors other. Islam views stress as a trial that every Muslim must face. Islam also provides solutions for stress, namely patience, tawakkal, and the discipline of worship. Other solutions for learning stress during the COVID-19 pandemic can also be in the form of problem-focused coping and emotional focused coping, web-based Solution-Focused Brief Counseling (SFBC), and spiritual, emotional freedom technique (SEFT).
\end{abstract}

Keywords: Learning Stress, Covid-19 Pandemic, Learning 


\section{A. Introduction}

It has been more than a year since the world was shocked by the Covid-19 disease (coronavirus disease 2019). First detected in Wuhan City, Hubei Province, China, the disease caused by the Sars-Cov-2 virus spread rapidly throughout the world, including Indonesia. The virus that causes respiratory problems to death has a high transmission power through direct transmission between humans (Handayani et al. 2020).

In order to reduce the spread of the COVID-19 virus, the government has made various policies. Starting from staying at home (stay at home), social restrictions (social distancing), physical restrictions (physical distancing), the use of personal protective equipment (masks), maintaining personal hygiene (washing hands), working and studying at home (work/ study from home), postpone all activities that gather large crowds, large-scale social restrictions (PSBB), and new normal policies (Tuwu 2020).

One of the impacts of this policy is Distance Learning (PJJ). As a form of work/study from the home application, PJJ is an education system with the characteristics of being open, learning independently by utilizing technology, information, and communication (Sari, Rifki, and Karmila 2020). Starting from the Elementary School, Junior High School, Senior High School to Higher Education levels, implementing this policy, both under the Ministry of Education and Culture of the Republic of Indonesia and the Ministry of Religion of the Republic of Indonesia (Purwanto et al. 2020). Face-to-face teaching and learning activities (KBM) at all levels are closed, replaced by learning using an online system.

Distance learning has several advantages. For example, it can be accessed anytime and anywhere. However, this learning system also has drawbacks, namely making students feel anxious and depressed due to a lack of understanding of the material and assignments (Oktawirawan 2020).

The low learning ethic of the participants in the learning process who was brave throughout the Covid-19 pandemic was shown by the attitude of students who did not appreciate the learning process, even they had fun in their world (such as playing games, streaming Youtube, sleeping, travelling) without a teacher is learning stress.

Factually, several cases that occur show that the low learning ethic of students in online learning includes the attitude of students who do not appreciate the learning 
process, even they are engrossed in their world (such as playing games, streaming YouTube, sleeping, travelling) regardless of the teacher who is explaining the material. This is one of the declines in the learning ethic caused by the fact that students are too heavy to bear the burden. Whether it is a moral or material burden or a family burden, it could be that the family is not very supportive in participating in learning and has an impact on learning stress. This, of course, causes students to fall behind in their learning.

This case has an impact on the learning ethos of students, so a learning completion model is needed that can relieve learning stress and encourage the increase of students' learning ethos in the learning process during the Covid-19 pandemic without conflicting with the spirit of the times with the support of existing educational, environmental factors. (Muhamad Ridwan Effendi, Rudi M. Barnansyah 2019).

Students of all levels feel the stress of studying due to the COVID-19 pandemic. Therefore, the author is interested in examining the effect of the COVID-19 pandemic on learning stress. This study aims to determine the factors influencing learning stress during the covid-19 pandemic and solutions to deal with learning stress.

\section{B. Theory / Concept}

\section{Definition of Stress}

Stress is a feeling of pressure as the body's response to a stressor in the form of something threatening. Stress can also be interpreted as pressure that occurs due to an imbalance between demands and a person's feeling of meeting these demands (Barseli, Ifdil, and Nikmarijal 2017), or a stressful biopsychosocial situation due to the many developmental tasks faced by individuals daily. These tasks can be in the form of tasks within the family, school, work, or peers (Rustiana and Cahyati 2012).

Stress is an unavoidable part of human life. Stress is a normal body reaction needed to motivate humans to be alert, adjust to the environment, and find solutions to overcome problems. This build-up stress is called eustress. Meanwhile, the type of stress that fails to build the individual is called distress (Diponegoro 2006).

Distress can be further divided into acute stress and chronic stress. In acute stress, the stressor activates the sympathetic nervous system, followed by the activation of adrenaline and cortisol. This response is a normal adaptive response, and the 
activation process will disappear in less than two hours. In comparison, chronic stress occurs when cortisol activation is excessive, and there is a disturbance in the receptors. This response is an abnormal response that is maladaptive and can harm health (Agatha 2019).

Figure 1. Acute Stress and Chronic Stress

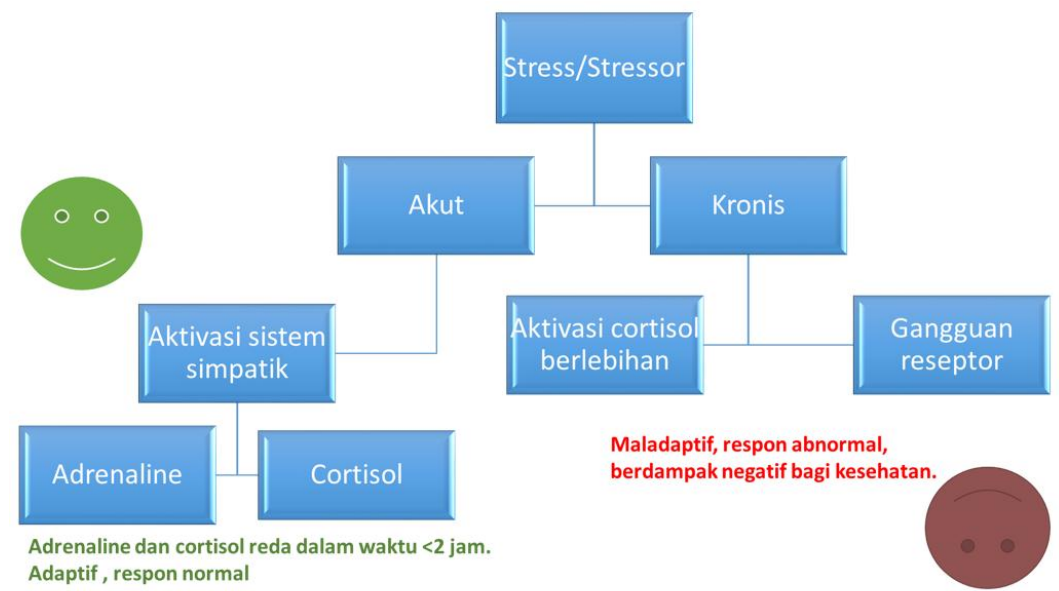

Source: (Agatha 2019)

Apart from eustress and distress, there are two other types of stress. Hyperstress is a term that refers to a type of negative stress when a person exerts more energy than needed. The opposite of this type of stress is hypostasis, which is the stress experienced by a person when feeling bored continuously (Tama and Hardiningtyas 2017).

Stages of stress according to research Dr Robert J. Van Amberg (Hasanah 2019).

\section{Stress Stage I}

This stress stage is the mildest and most adaptive stage characterized by feelings such as being eager to work hard, seeing sharper than usual, and solving problems better. Nevertheless, this stage also drains energy unconsciously.

\section{Stress Stage II}

Stress at this stage begins to cause complaints, such as feeling tired and tired after getting up, eating, and late in the afternoon. Physical symptoms such 
as feeling uncomfortable around the stomach and stomach, heart palpitations, and muscle tension are also indications of this stage of stress.

\section{Stress Stage III}

This stage is a continuation of the previous stage, involving more disturbing complaints. These include ulcers, irregular bowel movements, more pronounced muscle tension, sleep disturbances, and feelings like fainting.

\section{Stage IV Stress}

At this stage, individuals feel they can no longer carry out daily activities, lose interest in things that have initially been fun, sleep patterns are disturbed with stressful dreams, memory and concentration decline, and loss of enthusiasm or passion.

\section{Stage V Stress Stress}

The loss of passion and enthusiasm turns into fear and anxiety, but the individual cannot explain why he or she feels that way. Other symptoms at this stage also include worsening physical and mental fatigue, inability to complete easy tasks, worsening digestive system problems, and panic and confusion.

\section{Stress Stage VI}

This stage is the climax stage where individuals can experience panic attacks, very fast heartbeats, difficulty breathing, shortness of breath, shaking, sweating, and even fainting.

\section{Academic Stress / Study Stress}

Academic stress or learning stress is a category of distress, where students perceive academic demands as disturbing. The causes of academic stress are called academic stressors, which include pressure to go to class, get good grades, the obligation to do assignments, tests, and time management (Rahmawati 2016).

Academic stress can also be interpreted as pressure related to the ability to master a science experienced by students, both students and students. Indications can be 
physical, mental, and emotional disorders caused by the lack of sufficient actual power of students to meet these academic demands (Muslim 2020).

\section{Factors Affecting Academic Stress}

Factors that affect academic stress consist of internal and external factors. Internal factors can be in the form of mindset, personality, and beliefs of each individual. Individuals with wrong mindsets, pessimistic personalities, and the belief that they are not capable are more likely to experience academic stress. While external factors can be in the form of higher curriculum standards, they have increasingly crowded class schedules, intense competition, pressure to excel, the drive to achieve high social status through academic qualifications, and parents who compete with each other to show their children's superiority (Barseli et al. 2017 ).

Symptoms of academic stress include physical reactions, behavioural reactions, thought process reactions and emotional reactions (Azmy, Nurihsan, and Yudha 2017).

1. Physical reaction
a) Headache
b) The body is not able to rest optimally
c) Physical fatigue
d) Sweaty palms
e) Heart palpitations

2. Behavioral Reaction
a) Lying
b) Ditching
c) Grumbling
d) Blaming others
e) Fighting
f) Seek the attention of others
g) Nervous
h) Likes to be alone

3. Thinking Process Reaction

a) Difficulty concentrating

b) Decreased performance 

c) Perfectionist
d) Losing hope
e) Have no priorities in life
f) Negative thinking
g) Saturated

4. Emotional Reaction
a) Anxious
b) Easily offended
c) Not feeling satisfied
d) Feeling neglected

\section{Research Method}

The research method used by the researcher in this title is qualitative. Qualitative research can be explained as research intended to understand the phenomenon of what is experienced by research subjects by way of description in the form of language and words, in a unique natural context and by utilizing various natural methods (Moloeng 2016). Using qualitative research methods, researchers are expected to do better in conducting more proper research regarding the effect of the COVID-19 pandemic on stress in learning. The respondents in this study were students from schools or colleges in Jakarta, totalling 15 people and conducted based on a direct pull on the zoom platform.

In this study, the authors used a library search approach for data collection. Library search is a data collection technique by carrying out a review study of books, literature, notes, and reports that have to do with the problem being solved (Nazir 2013). The data taken by the researcher is the documentation contained in reading books, documents, papers and research journals that support the research material, namely the effect of the COVID-19 pandemic on stress in learning.

\section{Research Results and Discussion}

\section{Academic Stress During the Covid-19 Pandemic}

Several recent studies have shown that academic stress increases during the COVID-19 pandemic. This is considered related to the change in the face-to-face 
learning system to online (in the network), which raises new factors as a trigger for academic stress.

These trigger factors can be not understanding the material, task deadlines, unstable internet, difficulty doing assignments, internet quota constraints, technical problems, declining grades, being late for class, and not being ready to face the next level (Oktawirawan 2020).

Other factors can also be in the form of inadequate facilities and infrastructure, non-optimal learning absorption when adapting to a distance learning culture, and boredom at home due to no interaction with friends and teachers (Purwanto et al. 2020).

Academic stress can also be obtained from the accumulation of academic factors and social factors. In a study involving 1,129 students from various majors from 22 provinces in Indonesia, at least seven themes were factors of student academic stress. The themes include (1) learning assignments, (2) being bored with just being at home, (3) unable to meet loved ones, (4) boring learning process, (5) unable to do laboratory practice, (6) limited internet quota, and (7) unable to do hobbies as usual after the online learning system was implemented (PH, Fatkhul Mubin, and Basthomi 2020).

In addition to the factors above, in general, academic stress during a pandemic can also be influenced by the internal factors of each individual. These factors include achievement motivation (Sagita, Daharnis, and Syahniar 2017), psychological wellbeing (Edmawati 2020), self-efficacy (Utami, Rufaidah, and Nisa 2020), and emotional intelligence (Wijaya, Pamungkas, and Pramesta 2020).

Based on the explanation above, it can be seen that some of the factors that trigger academic stress are as follows.

a) Related material

Students feel they do not understand the material presented online. This is probably because not all teachers and lecturers are proficient in using technology as a learning medium. As a result, the material is not conveyed entirely and well. Lack of understanding of this material makes students feel anxious about their grades, and academic stress arises.

b) Task-related

The majority of students, both students and college students, complain of too much work during distance learning. The deadlines for these tasks are often 
close to each other. As a result, students feel overwhelmed and stressed to do the assignments on time.

c) Regarding value

The declining grades of students also cause academic stress during the pandemic. This decline in grades is related to a lack of understanding of the material and the inability to complete all assignments on time.

d) Regarding the learning system

The online learning system is considered tiring and boring. Students must sit in front of their devices and be exposed to radiation from cell phones, laptops, or computers for long periods. This, of course, makes the eyes and muscles tired. Doing this activity for months, of course, also makes students bored. This accumulation of fatigue and boredom then triggers academic stress.

e) Regarding facilities, quotas, and internet network jaringan

Online learning requires facilities and infrastructure such as devices, quotas, and a stable internet network. Unfortunately, not all students have these things in sufficient numbers. Most early childhood and elementary school students do not have a personal cell phone or laptop for learning. Not all students also have WiFi facilities at their residence, while the quota price is not low. Although the government promised a quota subsidy for students and teachers at all levels, the quota has not been received evenly. In addition, network constraints are difficult to avoid. The internet network is still difficult to access in some areas. Weather factors such as rain can also disrupt the internet network used for learning. As a result, students find it challenging to follow learning and experience academic stress.

\section{f) Regarding individual factors}

The psychological state of students also affects the chances of these students experiencing academic stress. Students who have low psychological well-being, self-efficacy, and emotional intelligence tend to be more prone to experiencing academic stress.

\section{1) Achievement motivation}

Students with low achievement motivation tend to feel burdened with their academic tasks. They often feel it compelled to do the task and force their 
energy closer to the exam or deadline for submitting assignments. As a result, they cannot absorb lessons optimally and are more likely to get poor grades, triggering academic stress. Meanwhile, students with high achievement motivation know their goals for studying and doing academic assignments, do not want to waste time and tend to do their best on assignments (Sagita et al., 2017).

\section{2) Psychological well-being}

Students with psychological well-being tend to have a stronger mentality when learning remotely online during the COVID-19 pandemic. They also tend to have stable emotions, high learning motivation, are not quickly bored in learning, accept the existing reality, and keep doing positive activities during unpleasant situations. They are also more capable of self-actualization. On the other hand, students with low levels of psychological well-being tend to experience decreased motivation to learn, are bored, emotionally unstable, and feel sudden mood changes. Therefore, they are more susceptible to academic stress during the COVID-19 pandemic (Edmawati 2020).

\section{3) Self-efficacy}

Self-efficacy can be interpreted as an individual's belief or confidence in his capacity to do a given task. Self-efficacy has a negative correlation with academic stress. The higher a person's self-efficacy, the lower the level of academic stress. However, research shows that student self-efficacy, especially college students, is in a low category during the COVID-19 pandemic, so it is not surprising that most students experience academic stress (Utami et al., 2020).

\section{4) Emotional intelligence}

Research on 57 college students aged 18-21 years showed that emotional intelligence was negatively correlated with academic stress. Emotional intelligence is an essential ability for a person to recognize personal and other people's emotions. About academic stress, an essential aspect of emotional intelligence is the ability to manage emotions and motivate oneself. Emotion management in question is the ability to regulate emotions when dealing with 
stressful situations or environmental stressors. Failure in the emotional management of stressors can cause stress (Wijaya et al., 2020).

\section{g) Related to social factors}

Distance learning not only affects the course of learning but also makes students socially inhibited. This has a significant impact on students with coping strategies that involve social activities. Tired of just being at home, not meeting loved ones, and not doing hobbies, as usual, are some of the complaints related to social factors that trigger academic stress.

\section{Islamic View of Stress}

In (Rena 2019), it is explained that stress based on the analysis of the verses of the Qur'an can be categorized into three terms, namely haul (anxious), you's (desperate), and qunut (helpless).

\section{a) Halu' (anxious)}

In the Qur'an Surah Al-Ma'arij verses 19-20, Allah SWT says, "Indeed, humans were created in a state of anxiety. When trouble afflicts him, he complains."

From the verse, it can be understood that feeling anxious is human nature. Humans tend to complain when faced with something unpleasant, and that is normal. Even so, Muslims are encouraged to be more grateful for the good things they have received rather than complaining.

\section{b) Ya's (desperate)}

Despair is a type of stress that is forbidden in Islam. As the word of Allah SWT in Surah Yusuf verse 87, “O my children, go you. So seek news about Joseph and his brother and do not despair of Allah's mercy. Verily, no one despairs of Allah's mercy except those who disbelieve."

\section{c) Qunut (helpless)}

Stress is often accompanied by feelings of helplessness, namely the feeling that you have no power to change yourself or change things for the better. In response to this, Allah SWT said in Surah Az-Zumar verse 53, "Say: "O My servants who transgressed 
against themselves, do not despair of Allah's mercy. Verily, He is the Most Forgiving, the Most Merciful."

Stress is one form of testing from Allah SWT, as explained in the following verse, "You will truly be tested on your wealth and yourself. Furthermore, (also) you will surely hear from those who were given the Book before you and from those who associate partners with Allah, many disturbances which hurt the heart. If you are patient and pious, then indeed, this is a matter that should be prioritized." (Surat Ali Imran verse 186).

\section{Solutions for Academic Stress during the Covid-19 Pandemic}

\section{Problem Focused Coping and Emotional Focused Coping}

Problem-focused coping and emotional focused coping is the most commonly used stress coping strategies. As the name implies, problem-focused coping is a coping strategy that focuses on problems that trigger stress. While emotional focused coping focuses on the emotions faced when experiencing stress. Examples of problem-focused coping, for example, when experiencing signal problems during distance learning, students look for places with access to a more stable internet network. While an example of focused emotional coping is when a student experiences stress, he tries to regulate his emotions and perspective on the stress he is experiencing. In everyday life, individuals cannot focus too much on problems without thinking about feelings or vice versa, focus too much on regulating emotions without solving problems. To deal with academic stress effectively, it is necessary to use these two coping strategies well (Fitriasari et al., 2020).

\section{Web-Based Solution-Focused Brief Counseling (SFBC)}

The results of the research conducted (Suranata and Prakoso 2020) showed that participants felt their academic stress levels decreased after participating in the web-based SFBC program. The SFBC program is a proven effective counselling method. The application of this program in the form of a website makes it very suitable for applying during the COVID-19 pandemic. 
Figure 2 SFBC Webpage
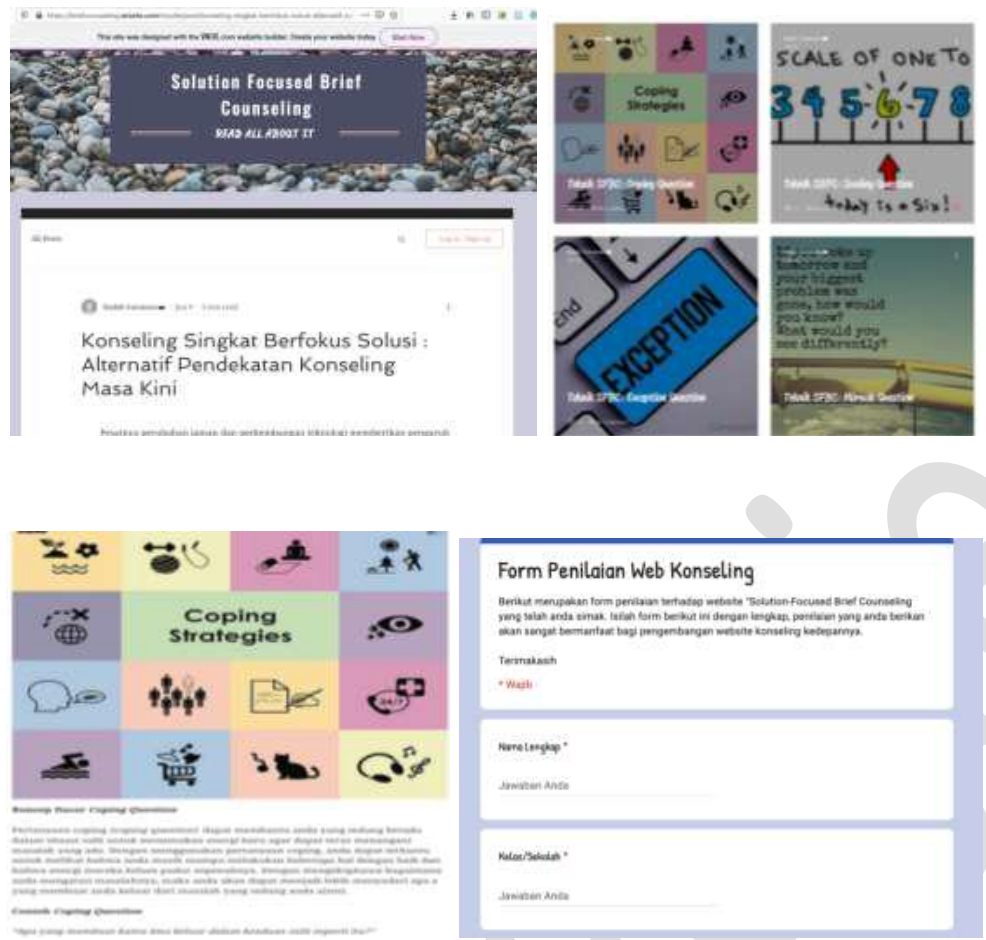

Source: (Suranata and Prakoso 2020)

\section{Spiritual Emotional Freedom Technique (SEFT) Therapy}

SEFT therapy is a therapy that uses relaxation techniques. This therapy combines the body's energy system and spiritual healing by tapping (light tapping) on 12 energy pathways at specific points on the body. More or less the same principle with acupuncture and acupressure. T tapping on SEFT therapy is lighter and emphasizes more on the spiritual element (prayer). SEFT therapy is also superior in terms of safety, convenience, and speed. Five main factors are crucial to the success of SEFT therapy, namely belief, sincerity, sincerity, Resignation, and gratitude. SEFT is proven to reduce academic stress levels (Rachmawati and Aristina 2019).

\section{a. Be patient}

Patience is a form of religious coping for a Muslim when facing life's problems, including academic stress. The suggestion to be patient is by the word of Allah, which reads, "Make patience and prayer as your helper. And verily this is very hard except for those who are humble, namely those who believe that they will meet their Lord and that they will return to Him." (Surat al-Baqarah verses 45-46). 
Patience can give a person the ability to survive the complexity of environmental demands and then find solutions to the problems he faces. The power of patience in reducing academic stress has been proven by research (Indria, Siregar, and Herawaty 2019).

\section{b. Resignation}

Research shows that the higher a person's level of tawakkal, the lower the level of academic stress. Tawakkal can be interpreted as believing that all events, which have occurred or will occur, whether in the form of trials or gifts, are entirely determined by Allah SWT. Tawakkal is often misunderstood as surrendering oneself, when in fact, the meaning is not that simple. A Muslim is obliged to pray and try hard before putting his trust or submitting the final result to Allah SWT. Believing that Allah's determination of the results to be obtained from his efforts is the best can prevent the individual from feeling anxious and thereby reduce his stress level. Therefore, practising tawakkal can be one of the religious coping strategies to prevent and overcome academic stress (Husnar, Saniah, and Nashori 2017).

\section{c. Discipline of worship}

Worship can be categorized into heart worship, oral worship, and body worship. Worship of the heart includes fear, hope, and trust in Allah SWT. Oral worship includes dhikr, such as saying Subhanallah (tasbih), Alhamdulillah (tahmid), Allahu Akbar (takbir), and Laa ilaha illallah (tahlil). In comparison, the worship of the limbs includes prayer, zakat, hajj, and jihad. Worshipping in a disciplined manner can bring peace in dealing with problems that occur in the academic environment. Discipline in worship means that worship is carried out by the procedures determined by religion, carrying out worship perfectly and solemnly, and being on time in worship with an exceptional execution time- the higher the Discipline of worship, the lower the academic stress (Hasan 2012).

\section{E. Closing}

Based on the study results, it can be concluded that the level of learning stress increases during the covid-19 pandemic. The things that affect this stress appear in various factors. Internal factors that affect learning stress are students who do not 
understand the material obtained online, lack of adapting to distance learning culture, which causes learning not to run optimally, and feeling bored with interactions at home without teachers and friends. Factors that arise from outside are also very influential related to the emergence of this stress, such as technical obstacles in the implementation of online learning, learning pressures that arise from the surrounding environment, and a tedious learning process (in this case, students only carry out online learning activities in front of their gadgets)., do not practice directly or do not use facilities that are generally used during offline learning). Other factors that can trigger learning stress are the number of tasks obtained during distance learning, decreased academic assessment due to understanding of the material and the inability to complete all assignments on time. The learning process is tiring because students must sit in front of the device and are exposed to radiation from the device screen. In an extended period, network constraints to accessing learning, social problems that occur in their environment, and several individual factors such as decreased motivation for achievement, psychological well-being of students, lack of self-confidence.

Stress is a form of test from Allah SWT. In Islam, stress can be categorized as halu' (anxiety), ya's (desperation), and qunut (helpless). In his word (Surah Ali Imran: 186), it is explained that humans will be tested for their wealth and themselves, disturbances will exist and hurt the heart, so patience and piety are things that must be prioritized. Patience can give someone the ability to survive the complexity of environmental demands and then find solutions to the problems they face. While piety is believing, and tawakkal is a form of effort. In addition to patience and tawakkal, there are other solutions to learning stress during the COVID-19 pandemic. Namely, problem-focused coping, emotional focused coping, web-based Solution-Focused Brief Counseling (SFBC), emotional freedom technique (SEFT), spiritual therapy, and course discipline in worship. 


\section{REFERENCES}

Agatha, Frastika. 2019. "Layanan Konseling Islami Dalam Menanggulangi Stres Belajar Siswa kelas XI SMA Negeri 1 Selesai Tahun Pelajaran 2018/2019." Universitas Islam Negeri Sumatera Utara.

Azmy, Amy Noerul, Achmad Juntika Nurihsan, dan Eka Skti Yudha. 2017. "Deskripsi

Gejala Stres Akademik dan Kecenderungan Pilihan Strategi Koping Siswa Berbakat." Indonesian Journal of Educational Counseling 1(2):197-208. doi: 10.30653/001.201712.14.

Barseli, Mufadhal, Ifdil Ifdil, dan Nikmarijal Nikmarijal. 2017. "Konsep Stres Akademik Siswa." Jurnal Konseling dan Pendidikan 5(3):143-48. doi: 10.29210/119800.

Diponegoro, Ahmad Muhammad. 2006. "Peran stress management terhadap kesejahteraan subjektif.” Humanitas: Jurnal Psikologi Indonesia 3(2).

Edmawati, Mahmuddah Dewi. 2020. "Strategi Konseling Kelompok dengan Teknik CBT Berbasis Daring untuk Meningkatkan Psychological Well Being Siswa di Tengah Pandemi Covid-19." Hal. 99-106 in Prosiding Seminar Bimbingan dan Konseling.

Fitriasari, Andikawati, Yurike Septianingrum, Syiddatul Budury, dan Khamida Khamida. 2020. "STRES PEMBELAJARAN ONLINE BERHUBUNGAN DENGAN STRATEGI KOPING MAHASISWA SELAMA PANDEMI COVID-19." Jurnal Keperawatan 12(4):985-92.

Handayani, Diah, Dwi Rendra Hadi, Fathiyah Isbaniah, Erlina Burhan, dan Heidy Agustin. 2020. “Penyakit Virus Corona 2019.” Jurnal Respirologi Indonesia 40(2):119-29. doi: https://doi.org/10.36497/jri.v40i2.101.

Hasan, Aliah B. Purwakania. 2012. "Disiplin Beribadah: Alat Penenang Ketika Dukungan Sosial Tidak Membantu Stres Akademik.” Jurnal Al-Azhar Indonesia Seri Humaniora 1(3):136-44. doi: 10.36722/sh.v1i3.63.

Hasanah, Muhimmatul. 2019. "STRES DAN SOLUSINYA DALAM PERSPEKTIF PSIKOLOGI DAN ISLAM." Jurnal Ummul Qura 13(1):104-16.

Husnar, Anni Zulfiani, Siti Saniah, dan Fuad Nashori. 2017. "Harapan, Tawakal, dan Stres Akademik." Psikohumaniora: Jurnal Penelitian Psikologi 2(1):94-105. doi: 
10.21580/pjpp.v2i1.1179.

Indria, Indah, Juliarni Siregar, dan Yulia Herawaty. 2019. "HUBUNGAN ANTARA KESABARAN DAN STRES AKADEMIK PADA MAHASISWA DI PEKANBARU.” An-Nafs: Jurnal Fakultas Psikologi 13(1):21-34.

Muslim, Moh. 2020. "MANAJEMEN STRESS PADA MASA PANDEMI COVID-19." ESENSI: Jurnal Manajemen Bisnis 23(2):192-201.

Moleong, Lexy J. 2016. Metodologi Penelitian Kualitatif. Edisi revisi. Bandung: PT. Remaja Rosdakarya.

Nazir, Moh. (2013). Metode Penelitian. Bogor: Ghalia Indonesia.

Oktawirawan, Dwi Hardani. 2020. "Faktor Pemicu Kecemasan Siswa dalam Melakukan Pembelajaran Daring di Masa Pandemi Covid-19.” Jurnal Ilmiah Universitas Batanghari Jambi 20(2):541-44. doi: 10.33087/jiubj.v20i2.932.

PH, Livana, Mohammad Fatkhul Mubin, dan Yazid Basthomi. 2020. “"TUGAS PEMBELAJARAN' PENYEBAB STRES MAHASISWA SELAMA PANDEMI COVID-19." Jurnal Ilmu Keperawatan Jiwa 3(2):203-8. doi: 10.32584/jikj.v3i2.590.

Purwanto, Agus, Rudy Pramono, Masduki Asbari, Choi Chi Hyun, Laksmi Mayesti Wijayanti, Ratna Setyowati Putri, dan Priyono Budi Santoso. 2020. "Studi Eksploratif Dampak Pandemi COVID-19 Terhadap Proses Pembelajaran Online di Sekolah Dasar." EduPsyCouns: Journal of Education, Psychology and Counseling 2(1):1-12.

Rachmawati, Nunung, dan Tenang Aristina. 2019. "Pengaruh Terapi Spiritual Emosional Freedom Technique (SEFT) Terhadap Stres Mahasiswa di Akademi Keperawatan 'YKY' Yogyakarta.' Jurnal Ners LENTERA 7(1):73-84.

Rahmawati, Weni Kurnia. 2016. "Efektivitas Teknik Restrukturisasi Kognitif Untuk Menangani Stres Akademik Siswa.” JKI (Jurnal Konseling Indonesia) 2(1):15-21.

Rena, Syahidah. 2019. “Mekanisme Respon Stres: Konseptualisasi Integrasi Islam Dan Barat.” Psikis: Jurnal Psikologi Islami 5(1):48-61. doi: 10.19109/psikis.v5i1.3116.

Rustiana, Eunike R., dan Widya Hary Cahyati. 2012. "Stress Kerja dengan Pemilihan Strategi Coping." KEMAS: Jurnal Kesehatan Masyarakat 7(2):149-55. doi: 10.15294/kemas.v7i2.2811. 
Sagita, Dony Darma, Daharnis, dan Syahniar. 2017. "Hubungan Self Efficacy, Motivasi Berprestasi, Prokrastinasi Akademik Dan Stres Akademik Mahasiswa." Bikotetik (Bimbingan dan Konseling: Teori dan Praktik) 1(2):43-52. doi: 10.26740/bikotetik.v1n2.p43-52.

Sari, Widya, Andi Muhammad Rifki, dan Mila Karmila. 2020. “ANALISIS KEBIJAKAN PENDIDIKAN TERKAIT IMPLEMENTASI PEMBELAJARAN JARAK JAUH PADA MASA DARURAT COVID 19.” Jurnal Mappesona 2(2).

Sugiyono. 2018. Metode penelitian, edisi ke-27. Bandung: Alfabeta

Suranata, Kadek, dan Bimoe Bagus Prakoso. 2020. "Program web-based SFBC untuk mereduksi kecemasan akademik siswa saat pandemi COVID-19; sebuah pilot studi." JPPI (Jurnal Penelitian Pendidikan Indonesia) 6(2):47-52. doi: 10.29210/02020609.

Tama, Ishardita Pambudi, dan Dewi Hardiningtyas. 2017. Psikologi Industri dalam Perspektif Sistem Industri. 1 ed. diedit oleh I. Nukman, A. Utaminingsih, dan A. M. Mawardi. Malang: Universitas Brawijaya Press.

Tuwu, Darmin. 2020. “Kebijakan Pemerintah Dalam Penanganan Pandemi COVID19." Journal Publicuho 3(2):267-78. doi: 10.35817/jpu.v3i2.12535.

Utami, Sri, Anna Rufaidah, dan Afiatin Nisa. 2020. "Kontribusi self-efficacy terhadap stres akademik mahasiswa selama pandemi Covid-19 periode April-Mei 2020.” TERAPUTIK: Jurnal Bimbingan dan Konseling 4(1):20-27. doi: 10.26539/teraputik.41294.

Wijaya, Priskilla Narendra, Noval Achmad Muamar Pamungkas, dan Dhea Karina Pramesta. 2020. "HUBUNGAN KECERDASAN EMOSIONAL DAN STRES AKADEMIK PADA MAHASISWA YANG MENGIKUTI ORGANISASI DAN SCHOOL FROM HOME.” Prosiding Seminar Nasional LP3M 2. 